\title{
Survival differences by ethnicity among patients diagnosed with bladder cancer
}

\author{
Boda Guo $0^{1,2}$ and Ming Liu' ${ }^{1,2^{*}}$ (i)
}

Dear Editor,

We read the study by Fang et al. [1] with great interest and would like to congratulate the authors for their superb study. The authors compared the oncologic outcomes of bladder cancer (BC) of different ethnicities, which may aid in clinical decision-making. As such, there are a few points that we would like to bring up.

1. Their study included patients with primary BC but did not exclude multiple primary cancers. However, another SEER-based study showed BC patients were at a significantly higher risk of developing a second malignancy, which may affect patients' survival [2].

2. BC surgery in the SEER database includes transurethral resection of bladder, partial cystectomy and complete cystectomy, etc. It would be more meaningful to stratify patients according to the type of surgery that they received; in this way, readers can easily see which surgical treatment improves BC patient's survival better.

3. Some of the patients included in the analysis received radiotherapy or chemotherapy. These two types of treatment should be taken into consideration since prior studies showed that both radiotherapy and chemotherapy hold great potential in the management of $\mathrm{BC}$ patients $[3,4]$.

This comment refers to the article available at https://doi.org/10.1186/s1296 7-020-02308-w.

*Correspondence: liumingbjhu@126.com

${ }^{1}$ Department of Urology, Beijing Hospital, National Center

of Gerontology; Institute of Geriatric Medicine, Chinese Academy

of Medical Sciences, Beijing 100730, China

Full list of author information is available at the end of the article
Abbreviation

BC: Bladder cancer.

\section{Acknowledgements \\ None.}

\section{Disclaimers}

The authors are accountable for all aspects of the work in ensuring that questions related to the accuracy or integrity of any part of the work are appropriately investigated and resolved.

\section{Authors' contributions}

$B G$ reviewed the relevant study and drafted this letter. ML revised this letter for critical content and scientific rigour. Both authors read and approved the final manuscript.

\section{Funding}

Not applicable.

\section{Availability of data and materials Not applicable.}

\section{Ethics approval and consent to participate} Not applicable.

\section{Consent for publication \\ Not applicable.}

\section{Competing interests}

Not applicable.

\section{Author details}

${ }^{1}$ Department of Urology, Beijing Hospital, National Center of Gerontology; Institute of Geriatric Medicine, Chinese Academy of Medical Sciences, Beijing 100730, China. ${ }^{2}$ Graduate School of Peking, Union Medical College, Beijing 100730, China.

Received: 29 October 2020 Accepted: 4 December 2020 Published online: 14 December 2020

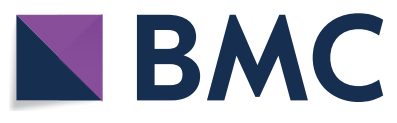

(c) The Author(s) 2020. This article is licensed under a Creative Commons Attribution 4.0 International License, which permits use, sharing, adaptation, distribution and reproduction in any medium or format, as long as you give appropriate credit to the original author(s) and the source, provide a link to the Creative Commons licence, and indicate if changes were made. The images or other third party material in this article are included in the article's Creative Commons licence, unless indicated otherwise in a credit line to the material. If material is not included in the article's Creative Commons licence and your intended use is not permitted by statutory regulation or exceeds the permitted use, you will need to obtain permission directly from the copyright holder. To view a copy of this licence, visit http://creativecommons.org/licenses/by/4.0/. The Creative Commons Public Domain Dedication waiver (http://creativecommons.org/publicdomain/zero/1.0/) applies to the data made available in this article, unless otherwise stated in a credit line to the data. 


\section{References}

1. Fang $W$, Yang $Z Y$, Chen TY, Shen XF, Zhang C. Ethnicity and survival in bladder cancer: a population-based study based on the SEER database. J Transl Med. 2020;18(1):145 (Epub 2020/04/02. Eng)

2. Khanal A, Budhathoki N, Singh VP, Shah BK. Second primary malignancy in bladder carcinoma-a population-based study. Anticancer Res. 2017:37(4):2033-6 (Epub 2017/04/05. Eng).

3. Diaz DA, Pollack A, Reis IM, Mahmoud O, Gonzalgo ML, Ishkanian A, et al. Neoadjuvant radiotherapy improves survival in patients with T2b/ T3 bladder cancer: a population-based analysis. Clin Genitourin Cancer. 2015;13(4):378-84 (Epub 2015/04/25. Eng)
4. Galsky MD, Stensland KD, Moshier E, Sfakianos JP, McBride RB, Tsao CK, et al. Effectiveness of adjuvant chemotherapy for locally advanced bladder cancer. J Clin Oncol. 2016;34(8):825-32 (Epub 2016/01/21. Eng).

\section{Publisher's Note}

Springer Nature remains neutral with regard to jurisdictional claims in published maps and institutional affiliations.
Ready to submit your research? Choose BMC and benefit from:

- fast, convenient online submission

- thorough peer review by experienced researchers in your field

- rapid publication on acceptance

- support for research data, including large and complex data types

- gold Open Access which fosters wider collaboration and increased citations

- maximum visibility for your research: over $100 \mathrm{M}$ website views per year

At BMC, research is always in progress.

Learn more biomedcentral.com/submissions 